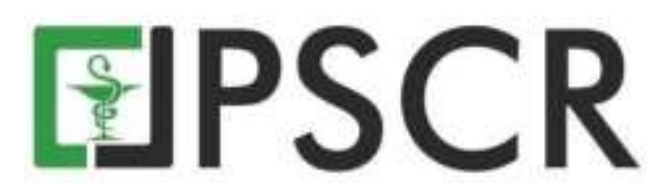

\title{
Aktivitas Imunomodulator Ekstrak Metanolik dan Fraksi Buah Talok (Muntingia calabura L.) terhadap Sel RAW 264.7
}

\author{
Tanti Azizah Sujono ${ }^{1 *}$, Ika Trisharyanti Dian Kusumowati ${ }^{2}$ dan Rima Munawaroh ${ }^{3}$ \\ ${ }^{1}$ Departemen Farmakologi dan Farmasi Klinik, Fakultas Farmasi, Universitas Muhammadiyah Surakarta, Jl. \\ Achmad Yani, Pabelan, Kartasura, Surakarta, Jawa Tengah, Indonesia, 57162 \\ ${ }^{2}$ Departemen Kimia Farmasi. Fakultas Farmasi, Universitas Muhammadiyah Surakarta, Jl. Achmad Yani, \\ Pabelan, Kartasura, Surakarta, Jawa Tengah, Indonesia, 57162 \\ ${ }^{3}$ Departemen Biologi Farmasi. Fakultas Farmasi, Universitas Muhammadiyah Surakarta, Jl. Achmad Yani, \\ Pabelan, Kartasura, Surakarta, Jawa Tengah, Indonesia, 57162 \\ *email korespondensi: tanti_azizah@ums.ac.id
}

Received 27 December 2020, Accepted 29 May 2021, Published 15 July 2021

\begin{abstract}
Abstrak: Buah talok (Muntingia calabura L) secara empiris telah diketahui mempunyai banyak manfaat bagi kesehatan, diantaranya adalah sebagai imunomodulator. Namun mekanisme aksinya sebagai imunomodulator belum diketahui secara pasti. Penelitian ini bertujuan untuk mengevaluasi efek imunomodulator ekstrak metanolik dan fraksi buah talok pada sel makrofag RAW 264.7. Sel RAW 264.7 diberi perlakuan dengan ekstrak metanolik buah talok (EMBT), fraksi heksan buah talok (FHBT), fraksi diklorometana buah talok (FDBT), fraksi etil asetat buah talok (FEABT) serta kelompok kontrol sel (KS), kontrol lipopolisakarida (LPS) dan deksametason. Viabilitas sel diukur dengan metode MTT assay dilanjutkan isolasi RNA, pembuatan cDNA dan PCR. Level ekspresi mRNA dari gen-gen seperti toll like receptor 4 (TLR4), interferon (IFN)- $\gamma$, interleukin (IL)-6, inducible nitric oxide synthase (iNOS), tumor necrosis factor (TNF)- $\alpha$ pada sel RAW 264.7 yang diinduksi lipopolisakarida (LPS) dianalisis dengan metode reverse transcription-PCR. Hasil penelitian menunjukkan bahwa deksametason menghambat ekspresi iNOS, IL-6, TNF- $\alpha$, TLR4, IFN- $\gamma$ dan NF-kB dibandingkan dengan kontrol sel dan LPS. Hal ini mengindikasikan bahwa deksametason mempunyai aktivitas antiinflamasi. Ekstrak metanolik (EMBT) dan fraksi buah talok (FHBT, FDBT dan FEABT) menurunkan ekspresi gen iNOS, TNF- $\alpha$, IL-6, IFN- $\gamma$ dan NF-kB jika dibandingkan dengan kontrol sel dan LPS, hal ini menunjukkan adanya aktivitas antiinflamasi. Ekstrak metanolik dan fraksi buah talok mempunyai aktivitas imunomodulator melalui penghambatan inflamasi dengan menurunkan ekspresi gen iNOS, TNF- $\alpha$, IL-6, IFN$\gamma$ dan NF-kB pada sel RAW 264.7 yang diinduksi LPS.
\end{abstract}

Kata kunci: Muntingia calabura L; MTT assay; sel RAW 264.7; Reverse TranscriptionPolymerase Chain Reaction (RT-PCR)

Abstract. The immumomodulatory activity of methanolic extract and its fraction of Talok fruits (Muntingia calabura L.) towards RAW 264.7 cells. Talok fruit (Muntingia calabura L) has been empirically known to have many health benefits, including as an immunomodulator. However, the mechanism of action as an immunomodulator is not certain. This study aimed to evaluate the immunomodulatory effects of talok fruit extract and fraction on RAW 264.7 macrophage cells. RAW 264.7 cells were treated with methanolic extract of talok fruit (EMBT), hexane fraction of talok fruit (FHBT), dichloromethane fraction of talok fruit (FDBT), ethyl acetate fraction of talok fruit (FEABT) as well as a cell control group, lipopolysaccharide control (LPS) and dexamethasone. After being tested for cell viability by the MTT assay method, then continued with RNA isolation, cDNA making and PCR. Expression levels of mRNA from toll like receptor 4 (TLR4), interferon (IFN)- $y$, interleukin (IL)-6, inducible nitric oxide synthase (iNOS), tumor necrosis factor (TNF)- $\alpha$ in 
lipopolysaccharide (LPS)-induced RAW 264.7 cells were analyzed using the reverse transcription-PCR method. The results showed that dexamethasone inhibited the expression of iNOS, IL-6, TNF- $\alpha$, TLR4 and NF-kB compared to cell control and LPS. This indicates that dexamethasone have antiinflammatory effect. Methanolic extract and fraction of talok fruits have immunomodulatory activity through inhibition of proinflammatory cytokines of iNOS, TNF- $\alpha$, IL-6, IFN- $\gamma$ and NF-kB in LPS-Induced RAW 264.7 cells.

Keywords: Muntingia calabura L; MTT assay; RAW 264.7 cells; Reverse TranscriptionPolymerase Chain Reaction (RT-PCR)

\section{Pendahuluan}

Tanaman talok (Muntingia calabura L.) banyak dijumpai di tepi jalan sebagai tanaman peneduh, selain itu buahnya juga bisa dikonsumsi. Buah talok memiliki kandungan vitamin $\mathrm{C}$ yang cukup tinggi, $\beta$-karoten, flavonoid, fenolik, niasin yang berkhasiat antara lain sebagai antiinflamasi (Preethi et al., 2012), antioksidan (Preethi et al., 2010; Siddiqua et al., 2010), antirematik (Sarimanah et al., 2017) dan juga imunomodulator (Prakosa, 2014; Sujono et al., 2020). Imunomodulator merupakan zat yang dapat memodulasi sistem kekebalan tubuh baik sebagai imunostimulan (meningkatkan sistem imun) ataupun imunosupresan (menurunkan sistem imun) (Sasmito, 2017).

Buah talok diduga memiliki efek imunomodulator karena mengandung senyawa golongan flavonoid dan polifenol. Kandungan flavonoid memiliki banyak aktivitas farmakologis diantaranya sebagai imunomodulator (Patel \& Vajdy, 2015). Kebanyakan turunan fenolik pada tumbuhan mempengaruhi respon imun non spesifik terutama melalui peningkatan fagositosis dan limfosit serta proliferasi neutrofil (Grigore, 2017). Mekanisme aksi imunomodulator buah talok sampai saat ini belum diketahui secara pasti. Penelitian sebelumnya menunjukkan bahwa ekstrak metanolik dan fraksi etil asetat talok memiliki efek imunomodulator terhadap respon imun non spesifik dengan meningkatkan indeks fagositik (Sujono et al., 2020). Namun sampai saat ini belum ada penelitian yang menguji aktivitas imunomodulator buah talok terhadap ekspresi gen inflamasi seperti iNOS, TNF- $\alpha$, dan IL-6 pada sel RAW 264.7 yang diinduksi lipopolisakarida (LPS) menggunakan metode reverse transcription-PCR.

Makrofag merupakan salah satu sel imun yang bisa mengekspresikan reseptor TLR4 yang dapat mengenali endotoksin lipopolisakarida (LPS) dari bakteri Gram negatif. Selanjutnya akan memberi sinyal transduksi melalui TLR4 dan mengaktifkan respon imun innate serta menstimulasi berbagai protein yang penting bagi fungsi makrofag (Baratawidjaja \& Rengganis, 2016). TLR4 bisa menstimulasi produksi faktor transkripsi NF-kB yang memproduksi berbagai protein dan sejumlah sitokin proinflamasi seperti iNOS, IL-6, TNF- $\alpha$ yang berperan dalam respon imun (Muniandy et al., 2018). Senyawa imunomodulator dapat 
mempengaruhi ekspresi gen proinflamasi tersebut. Inflamasi merupakan respon biologis yang penting terhadap cedera. Selama proses peradangan, makrofag akan memproduksi sitokin dan melepaskan mediator inflamasi. Untuk mengobati inflamasi yang bersifat kronis diperlukan suatu antiinflamasi (Dewi et al., 2015). Buah talok dapat dimanfaatkan sebagai antiinflamasi (Preethi et al., 2012). Yahfoufi et al menyatakan bahwa senyawa polifenol dapat memodulasi sistem imun dengan mempengaruhi regulasi sel yang berperan dalam imun, sintesis sitokin proinflamasi, dan juga ekspresi gen (Yahfoufi et al., 2018).

Sel RAW 264.7 merupakan cell line monosit atau makrofag yang berasal dari mencit Balb/c. Pada banyak penelitian, sel RAW 264.7 digunakan sebagai model makrofag untuk mempelajari respon imun terutama innate. Berdasarkan hal di atas maka penelitian ini penting dilakukan untuk mengetahui aktivitas imunomodulator ekstrak dan fraksi buah talok terhadap ekspresi gen-gen yang terlibat pada proses inflamasi yang berperan pada regulasi sistem imun menggunakan kultur sel RAW 264.7 in vitro.

\section{Bahan dan Metode}

\subsection{Bahan}

Buah talok segar diperoleh dari daerah Bantul, Yogyakarta. Identifikasi tanaman talok dilakukan di Laboratorium Farmakognosi Jurusan Biologi Farmasi Fakultas Farmasi Universitas Gadjah Mada Yogyakarta dengan nomor: 18.2.9/UN1/FFA/BF/PT/2019. Penyari untuk maserasi dan fraksinasi meliputi metanol (teknis), n-heksan (teknis), diklorometana (Merck), etil asetat (teknis). Sel RAW 264.7 diperoleh dari Laboratorium Parasitologi Fakultas Kedokteran Kesehatan Masyarakat dan Keperawatan (FKKMK) Universitas Gadjah Mada. Media yang digunakan untuk memelihara sel RAW yaitu Dulbecco's Modified Eagle's Medium (DMEM) yang disuplementasi dengan fetal bovine serum (FBS) 10\% diperoleh dari Laboratorium FKKMK Universitas Gadjah Mada. Lipopolysaccharides dari Eschericia coli 0111.B4 (Sigma-Aldrich), Dexamethasone injeksi (Harsen). Total RNA Mini Kit (Geneaid) digunakan untuk isolasi RNA sel RAW, Rever Tra Ace- $\alpha$ (TOYOBO) digunakan untuk membuat cDNA, GoTaq ${ }^{\circledR}$ Green (Promega), Nuclease-Free Water (Promega). Bahan yang digunakan untuk elektroforesis meliputi TBE (Vivantis), Agarose gel (GeneDireX), FluoroVue $^{\mathrm{TM}}$ Nucleic Acid Gel Stain (SMOBIO), AccuBand ${ }^{\mathrm{TM}} 100$ bp+3K DNA ladder II (SMOBIO).

\subsection{Metode}

\subsubsection{Ekstraksi dan fraksinasi buah talok}

Buah talok segar sebanyak 4,9 kg buah talok segar (M. calabura L.) dicuci dengan air mengalir. Selanjutnya buah dikeringkan dalam oven pada suhu $50^{\circ} \mathrm{C}$ selama 7 hari. Buah 
talok yang sudah kering lalu diblender menghasilkan 1,543 kg serbuk kering. Selanjutnya serbuk dimaserasi menggunakan 10,5 liter metanol selama 3 hari. Filtrat diuapkan menggunakan rotary evaporator untuk mendapatkan ekstrak metanolik kental, selanjutnya dipekatkan di atas waterbath selama 3 hari menghasilkan ekstrak metanolik kental buah talok (EMBT).

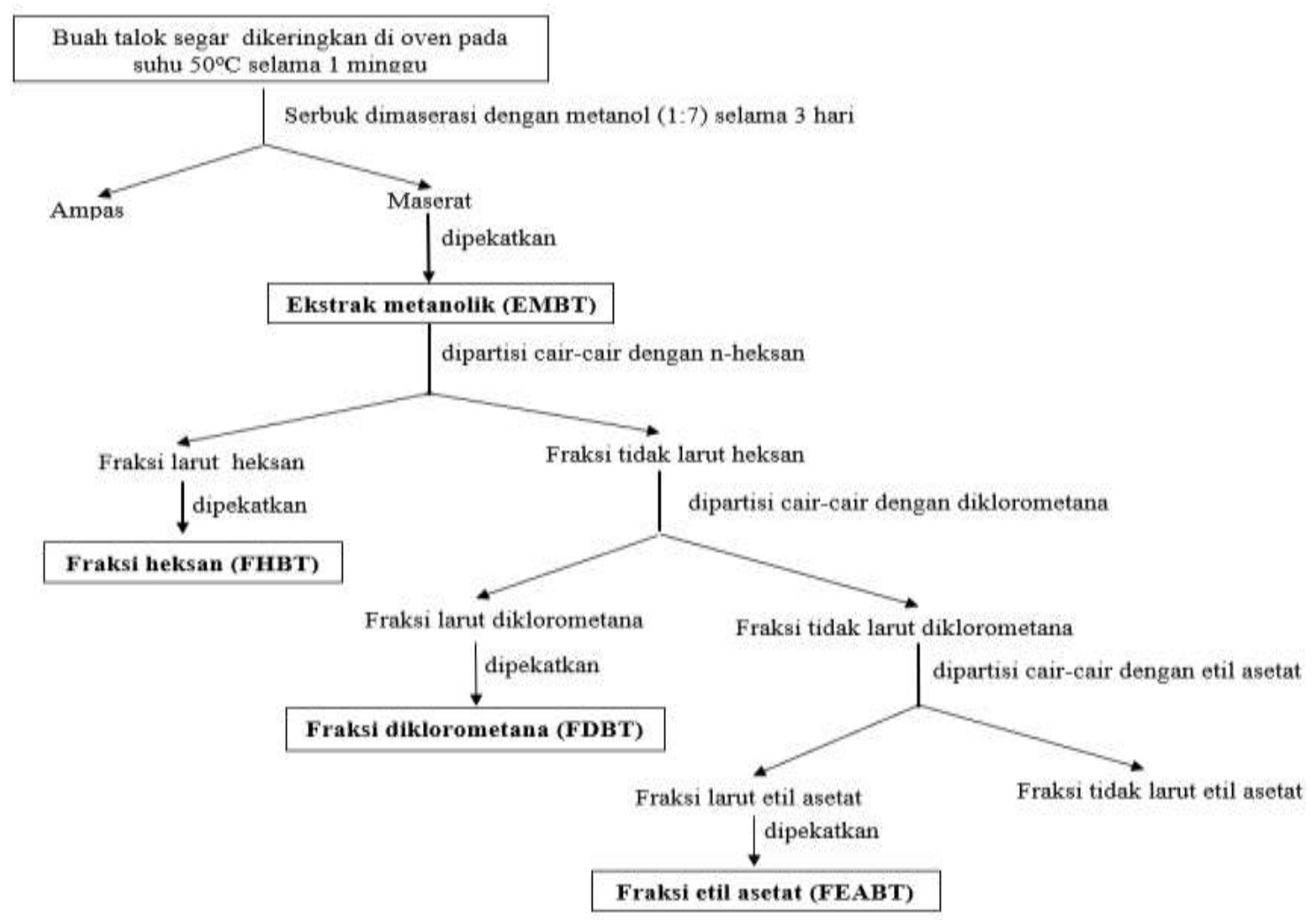

Gambar 1. Skema ekstraksi dan fraksinasi buah talok (Muntingia calabura L.) menggunakan metode partisi cair-cair.

Fraksinasi dilakukan setiap 10 gram ekstrak metanolik buah talok (EMBT) dilarutkan dalam $100 \mathrm{~mL}$ air kemudian dilakukan partisi cair-cair menggunakan $100 \mathrm{~mL}$ heksan sampai fase heksan jernih (3x partisi) dalam corong pisah. Fase larut heksan selanjutnya diuapkan dengan rotary evaporator lalu dipekatkan di atas water bath selama 3 hari, diperoleh fraksi heksan (FHBT). Selanjutnya tiap $100 \mathrm{~mL}$ fase tak larut heksan dipartisi cair-cair menggunakan diklorometana $100 \mathrm{~mL}$ sampai jernih (3x partisi). Fase larut diklorometana dipisahkan dan diuapkan menggunakan rotary evaporator, selanjutnya dipekatkan di atas water bath suhu $60^{\circ} \mathrm{C}$ selama 3 hari, diperoleh fraksi diklorometana (FDBT). Proses selanjutnya tiap $100 \mathrm{~mL}$ fase tak larut diklorometana dipartisi cair-cair dengan $100 \mathrm{~mL}$ etil asetat sampai jernih (3x partisi). Fase larut etil asetat dipisahkan dan diuapkan menggunakan rotary evaporator suhu $50^{\circ} \mathrm{C}$, selanjutnya dipekatkan di atas water bath suhu $60^{\circ} \mathrm{C}$ selama 3 hari, diperoleh fraksi etil asetat (FEABT). Skema proses ekstraksi dan fraksinasi buah talok 
(Muntingia calabura L.), yakni ekstrak metanolik (EMBT), fraksi heksan (FHBT), fraksi diklorometana (FDBT) dan fraksi etil asetat (FEABT) dapat dilihat pada Gambar 1.

\subsubsection{Uji aktivitas imunomodulator menggunakan sel RAW 264.7}

- Uji viabilitas sel menggunakan LPS

Uji viabilitas sel RAW 264.7 mengacu pada penelitian sebelumnya (Rosidah et al., 2019) dengan sedikit modifikasi pada kepadatan sel yang digunakan. Sel RAW 264.7 ditumbuhkan dalam medium komplit (MK-DMEM) yang berisi DMEM, PenicillinStreptomycin 2\%, Fungizone (Amphotericin B) 0,5\% dan FBS 10\%. Penicillin-Streptomycin sebagai antibakteri, dan Fungizone (Amphotericin B) sebagai antifungi. Sel ditanam dengan kepadatan 4000 sel/well, sebanyak 100 uL tiap well pada mikroplate 96 well dan diinkubasi dengan inkubator $\mathrm{CO}_{2}$ pada suhu $37^{\circ} \mathrm{C}$ selama 24 jam, selanjutnya media dibuang dan diberi ekstrak dan fraksi buah talok sebanyak $100 \mu$ tiap well dengan seri konsentrasi 400, 200, 100, 50,25 dan $12,5 \mu \mathrm{g} / \mathrm{mL}$.

Seri konsentrasi ekstrak dan fraksi buah talok dibuat dengan cara terlebih dulu disiapkan MK-DMEM yang sudah mengandung LPS $1 \mu \mathrm{g} / \mathrm{mL}(0,1 \mu \mathrm{g} / 100 \mu \mathrm{L})$, yang dibuat dengan cara melarutkan $1 \mathrm{mg}$ LPS dalam 0,5 mL PBS (stok LPS $2000 \mu \mathrm{g} / \mathrm{mL}$ ) dengan rumus pengenceran lalu diambil $5 \mu \mathrm{L}$ LPS stok ditambah MK-DMEM ad $10.000 \mu \mathrm{L}$ ). Selanjutnya ditimbang 10 mg ekstrak atau fraksi buah talok, lalu dilarutkan dalam $100 \mu \mathrm{L}$ DMSO (diperoleh konsentrasi $100.000 \mu \mathrm{g} / \mathrm{mL}$ ). Setelah itu dibuat larutan stok ekstrak atau fraksi buah talok $1000 \mu \mathrm{g} / \mathrm{mL}$ dengan rumus pengenceran (diambil $10 \mu \mathrm{L}$ dari stok awal ditambah $990 \mu \mathrm{L}$ MK-DMEM yang sudah mengandung LPS $1 \mu \mathrm{g} / \mathrm{mL}$ ). Selanjutnya dari stok $1000 \mu \mathrm{g} / \mathrm{mL}$ dibuat 6 seri konsentrasi yaitu 400, 200, 100, 50, 25, $12,5 \mu \mathrm{g} / \mathrm{mL}$.

Microplate 96 well selanjutnya diberi ekstrak dan fraksi buah talok lalu dinkubasi kembali selama 24 jam. Selanjutnya media dibuang lalu diberi MTT (3-(4,5-dimethyl-2thiazolyl)-2,5-diphenyl-2H-tetrazolium bromide) sebanyak $100 \mu$ tiap well (cara membuat:1 mL MTT 5 mg/mL ditambah MK-DMEM ad 10 mL), 4 jam kemudian diberi 100 uL stopper SDS (sodium dodecyl sulphate) $10 \%$ dalam $\mathrm{HCl}$ 0,01 N. Setelah diinkubasi selama 24 jam, absorbansi diukur menggunakan microplate reader (BIO RAD Microplate Reader Benchmark) pada panjang gelombang $550 \mathrm{~nm}$.

\section{- Isolasi RNA}

Sel RAW 264.7 dengan kepadatan $500.000 \mathrm{sel} /$ well ditanam pada 6-well plate, tiap well berisi $2 \mathrm{~mL}$ (kepadatan $500.000 \mathrm{sel} / 2 \mathrm{~mL}$ ). Kemudian diinkubasi dalam inkubator $\mathrm{CO}_{2}$ suhu $37^{\circ} \mathrm{C}$ selama 24 jam. Selanjutnya media diganti dengan media baru lalu diinduksi dengan lipopolisakarida $(2 \mu \mathrm{g} / \mathrm{mL})$ dan diinkubasi kembali selama 6 jam, lalu ditambahkan larutan uji 
ekstrak metanolik buah talok (EMBT), fraksi heksan buah talok (FHBT), fraksi diklorometana buah talok (FDBT), fraksi etil asetat buah talok (FEABT) dengan konsentrasi $25 \mu \mathrm{g} / \mathrm{mL}$ (konsentrasi ini diperoleh dari hasil uji viabilitas sel di mana pada konsentrasi tersebut viabilitas sel di atas 90\%) dan deksametason 2,5 $\mu \mathrm{g} / \mathrm{mL}$. Selanjutnya diinkubasi kembali selama 24 jam, lalu media dipindahkan dalam tabung, sel dicuci sebanyak 1 kali dengan $2 \mathrm{~mL}$ PBS steril dan disentrifugasi dengan kecepatan $3000 \mathrm{rpm}$ selama 5 menit, lapisan paling atas dibuang dan endapan dikumpulkan kemudian dilanjutkan dengan ekstraksi RNA menggunakan Total RNA mini kit (Geneaid) berdasarkan protokol dari pabrikan yang ada di leafletnya.

- Pembuatan cDNA

RNA yang telah diperoleh selanjutnya dibuat cDNA, yakni sebanyak 3000 ng RNA ditambah DNase RNase free water hingga volume total $12 \mu \mathrm{L}$. Sebanyak $8 \mu \mathrm{L}$ larutan campuran (5x RT-buffer $4 \mu \mathrm{L}$, random primer I $\mu \mathrm{L}$, dNTP $2 \mu \mathrm{L}$, Rever Tra-Ace $1 \mu \mathrm{L}$ ) ditambahkan pada tiap microtube yang berisi RNA, kemudian diresuspensi dan dilakukan PCR dengan kondisi $30^{\circ} \mathrm{C}$ selama 10 menit, $42^{\circ} \mathrm{C}$ selama 60 menit, dan $99^{\circ} \mathrm{C}$ selama 5 menit. Produk PCR hasil pembuatan cDNA diukur konsentrasinya dengan menggunakan alat nanodrop (NanoQuant Plate TECAN Spark). Selanjutnya dibuat stok DNA 100 ng sebanyak $100 \mu$ Luntuk RT-PCR.

Tabel 1. Sekuen primer oligonukleotida mencit yang digunakan untuk reverse transcriptasePCR dan suhu annealingnya.

\begin{tabular}{|c|c|c|c|c|}
\hline Gen & & Sekuen primer & $\begin{array}{c}\text { ukuran } \\
\text { (bp) }\end{array}$ & $\begin{array}{c}\text { Suhu } \\
\text { Annealing }\left({ }^{\circ} \mathrm{C}\right) \\
\end{array}$ \\
\hline TLR4 & $\begin{array}{l}\mathrm{F} \\
\mathrm{R}\end{array}$ & $\begin{array}{l}\text { GGGCCTAAACCCAGTCTGTTTG } \\
\text { GCCCGGTAAGGTCCATGCTA }\end{array}$ & 118 & 56 \\
\hline NF-kB & $\begin{array}{l}\mathrm{F} \\
\mathrm{R}\end{array}$ & $\begin{array}{l}\text { GCGTACACATTCTGGGGAGT } \\
\text { ACCGAAGCAGGAGCTATCAA }\end{array}$ & 179 & 57 \\
\hline IFN- $\gamma$ & $\begin{array}{l}\mathrm{F} \\
\mathrm{R}\end{array}$ & $\begin{array}{l}\text { TCAAGTGGCATAGATGTGGAAGAA } \\
\text { TGGCTCTGCAGGATTTTCATG }\end{array}$ & 92 & 58 \\
\hline IL-6 & $\begin{array}{l}\mathrm{F} \\
\mathrm{R}\end{array}$ & $\begin{array}{l}\text { CGCACTAGGTTTGCCGAGTA } \\
\text { CCCCAATTTCCAATGCTCTCC }\end{array}$ & 141 & 58 \\
\hline iNOS & $\begin{array}{l}\mathrm{F} \\
\mathrm{R}\end{array}$ & $\begin{array}{l}\text { CGAAACGCTTCACTTCCAA } \\
\text { TGAGCCTATATTGCTGTGGCT }\end{array}$ & 311 & 60 \\
\hline TNF- $\alpha$ & $\begin{array}{l}\mathrm{F} \\
\mathrm{R}\end{array}$ & $\begin{array}{l}\text { TGTGCCGCCGCTGTCTGCTTCACGCT } \\
\text { GATGAGGAAAGACACCTGGCTGTAGA }\end{array}$ & 374 & 55 \\
\hline$\beta$-actin & $\begin{array}{l}\mathrm{F} \\
\mathrm{R}\end{array}$ & $\begin{array}{l}\text { TGGAATCCTGTGGCATCCATGAAAC } \\
\text { TAAAACGCAGCTCAGTAACAGTCCG }\end{array}$ & 349 & 55 \\
\hline
\end{tabular}

- Analisis ekspresi gen

Ekspresi gen iNOS, TNF- $\alpha$, IL-6, IFN- $\gamma$, NF-kB, TLR4 dan $\beta$-actin diperiksa dengan cara mengambil $1 \mu \mathrm{L}$ cDNA $100 \mathrm{ng} / \mu \mathrm{L}$ ditambahkan sampai $25 \mu \mathrm{L}$ ((PCR Master Mix (GoTaq Green) $12,5 \mu \mathrm{L}$, primer forward $1 \mu \mathrm{L}$, primer reverse $1 \mu \mathrm{L}$, DNase RNase free water 
9,5 $\mu \mathrm{L}$ ). Ekspresi gen TNF- $\alpha$, IL-6, iNOS, NF-kB, TLR4, IFN- $\gamma$ dan $\beta$-actin ditentukan dengan metode reverse transcriptase-PCR. Sedangkan primer oligonukleotida untuk TNF- $\alpha$, IL-6, iNOS, NF-kB, TLR4, IFN- $\gamma$ dan $\beta$-actin dirancang berdasarkan program seleksi primer pada website dari Gen Bank database (Auliafendri et al., 2019). Sekuen primer beserta suhu annealing dapat dilihat pada Tabel 1.

PCR terdiri dari 35 siklus amplifikasi dan setiap siklus dilakukan selama 30 detik pada $95^{\circ} \mathrm{C}$ (denaturasi), 1 menit pada suhu annealing dan 1 menit pada $72^{\circ} \mathrm{C}$ (elongasi) dalam thermal cycler (Bio-Rad). Sebagai kontrol internal digunakan $\beta$-actin yang merupakan house keeping gene untuk menstandarisasi tingkat ekspresi relatif untuk semua biomarker (Yanti et al., 2011). Produk PCR dianalisis dengan elektroforesis menggunakan agarose $2 \%$ serta FluoroVue $^{\mathrm{TM}}$ (Nucleic Acid Gel Stain, SMOBIO) 10.000X no. katalog NS1000 $500 \mu \mathrm{L}$ x 1 vial sebagai pewarna. Gel divisualisasi densitometri menggunakan software Gel-Doc (Bio$\mathrm{Rad})$.

\subsubsection{Analisis data}

Semua data disajikan dalam bentuk rata-rata \pm standard error of the mean (SEM) dengan replikasi sebanyak 3 kali. Data dianalisis dengan metoda Anova 1 arah dengan taraf kepercayaan $95 \%$. Jika terdapat perbedaan yang signifikan $(\mathrm{p}<0,05)$ dilanjutkan uji post hoc LSD (Least Significant difference) menggunakan software SPSS 22.

\section{Hasil dan Pembahasan}

Ekstraksi dengan pelarut metanol bertujuan untuk menarik senyawa yang bersifat polar, sedangkan fraksinasi cair-cair menggunakan pelarut dengan polaritas yang berbeda (n-heksan, diklorometana, dan etil asetat) untuk menarik senyawa yang bersifat non polar hingga semipolar. Total sebanyak 467,8 g ekstrak metanolik buah talok (30,30\%), dipisahkan menggunakan partisi cair-cair sehingga diperoleh fraksi heksan 2,40 $\mathrm{g}(0,50 \%)$; fraksi diklorometana 2,80 g (0,59\%); dan fraksi etil asetat 6,60 g (1,40\%). Fraksi etil asetat (FEABT) mempunyai konsistensi yang lebih kering jika dibandingkan dengan fraksi heksan (FHBT) dan fraksi diklorometana (FDBT).

Kandungan flavonoid dan fenolik dalam ekstrak metanolik buah talok diduga bertanggung jawab atas aktivitas imunomodulatornya (Pereira et al., 2018). Ekstrak etanol dan etil asetat buah talok positif mengandung flavonoid dan fenolik (Senet et al., 2012).

\subsection{Aktivitas imunomodulator buah talok pada sel RAW 264.7 in vitro}

Pada penelitian ini digunakan lipopolisakarida (LPS) yang secara luas dikenal sebagai penginduksi produksi sitokin inflamatori yang akan menstimulasi produksi iNOS selama proses inflamasi pada makrofag (Joo et al., 2014). 
Uji viabilitas sel dilakukan untuk mengetahui pengaruh ekstrak dan fraksi buah talok terhadap viabilitas sel RAW 264.7 serta untuk menentukan konsentrasi ekstrak dan fraksi buah talok yang tidak toksik saat digunakan pengujian aktivitas imunomodulator. Konsentrasi senyawa uji (ekstrak dan fraksi buah talok) yang diberikan adalah 12,5, 25, 50, 100, 200 dan $400 \mathrm{ug} / \mathrm{mL}$. Hasil uji viabilitas sel menunjukkan bahwa ekstrak metanolik dan fraksi buah talok pada konsentrasi 12,5, 25 dan $50 \mu \mathrm{g} / \mathrm{mL}$ mempunyai persentase viabilitas sel tertinggi dimana ekstrak tidak menunjukkan toksisitas terhadap sel RAW 264.7 yakni viabililitas sel di atas $90 \%$ (Tabel 2). Keterbatasan dalam penelitian ini adalah tidak dilakukannya uji viabilitas sel terhadap fraksi diklorometana (FDBT) dan fraksi etil asetat (FEABT).

Tabel 2. Nilai rata-rata \% viabilitas dari ekstrak metanolik buah talok (EMBT) dan fraksi heksan buah talok (FHBT).

\begin{tabular}{ccc}
\hline $\begin{array}{c}\text { Konsentrasi } \\
(\boldsymbol{\mu g} / \mathbf{m L})\end{array}$ & \multicolumn{2}{c}{ \% rata-rata viabilitas sel \pm SEM } \\
\cline { 2 - 3 } & EMBT & FHB T \\
\hline 12,5 & $99,70 \pm 2,18$ & $95,10 \pm 2,60$ \\
50 & $94,26 \pm 0,55$ & $93,47 \pm 0,78$ \\
100 & $93,18 \pm 1,20$ & $98,42 \pm 0,88$ \\
200 & $79,03 \pm 1,72$ & $92,88 \pm 2,43$ \\
& $45,10 \pm 2,56$ & $89,52 \pm 1,31$ \\
\hline
\end{tabular}

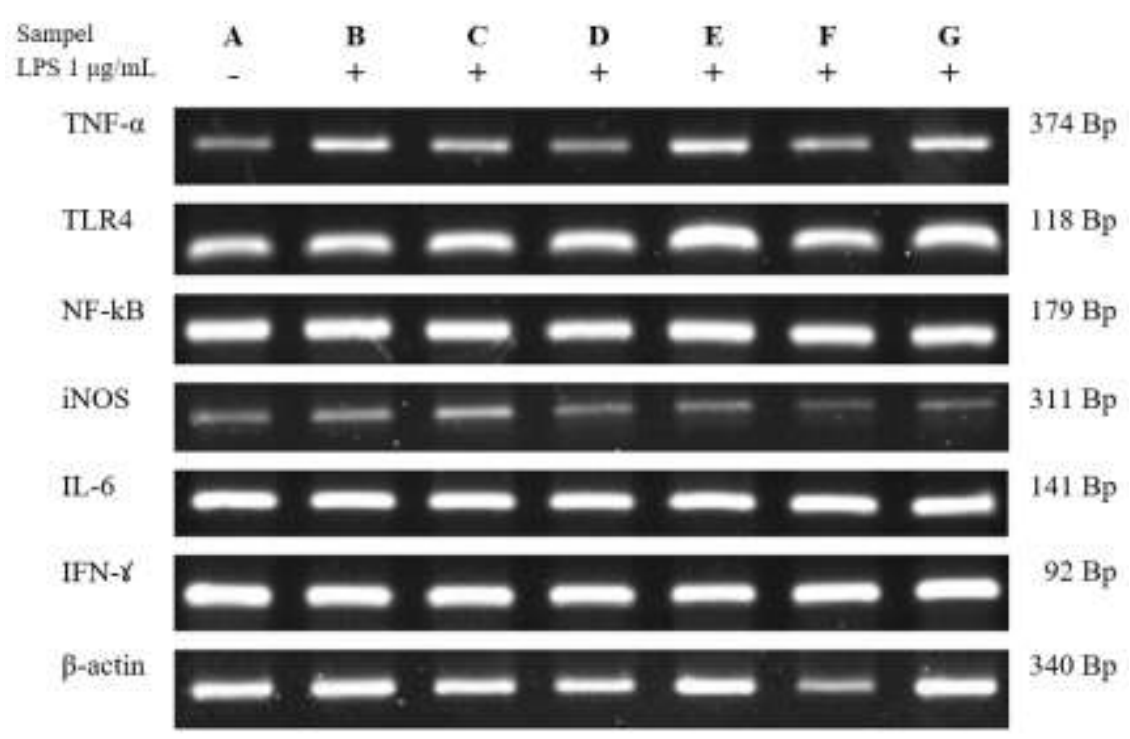

Gambar 2. Efek ekstrak dan fraksi buah talok terhadap ekspresi gen pada sel RAW 264.7 yang diinduksi LPS $1 \mu \mathrm{g} / \mathrm{mL}$ selama 6 jam. Total RNA diisolasi dan RT-PCR dilakukan dengan menggunakan primer TNF- $\alpha$, TLR4, NF-kB, iNOS, IL-6, IFN- $\gamma, \beta$-actin. Kontrol sel (A), LPS (B), FDBT (C), FEABT (D), EMBT (E), FHBT (F), deksametason 2,5 $\mathrm{gmL}^{-1}(\mathrm{G})$. $\beta$-actin digunakan sebagai kontrol internal. LPS (Lipopolysaccharide), RT-PCR (Reverse Transcription-PCR), iNOS (Inducible Nitric Oxide Synthase) IL (interleukin)-6, TLR4 (Toll Like Receptor 4), NF-kB (Nuclear Factor kappa B), Bp (Base Pair).

Makrofag yang teraktivasi akan mencegah terhadap invasi patogen dengan mengeluarkan mediator inflamasi seperti nitric oxide (NO) dan sitokin seperti TNF- $\alpha$ dan 
interleukin (Kwon et al., 2016). Hasil ekspresi gen akibat pemberian FDBT, FEABT, EMBT dan FHBT serta deksametason dianalisis menggunakan metode reverse trancriptase-PCR. Hasil dapat dilihat pada Gambar 2.

Pada penelitian ini digunakan lipopolisakarida (LPS), suatu substansi yang digunakan untuk mengaktifkan makrofag. LPS merupakan endotoksin yang berasal dari membran luar sel bakteri Gram negatif yang dapat mengaktifkan makrofag melalui jalur aktivasi persinyalan seluler, sehingga dapat menstimulasi transkripsi gen-gen seperti iNOS, dan sitokin yang terkait makrofag seperti IL-6, TNF- $\alpha$ (Kwon et al., 2016). Makrofag yang teraktivasi akan memicu terjadinya inflamasi dengan melepaskan mediator inflamasi seperti TNF- $\alpha$, IL-6 (Fard et al., 2015). Deksametason pada penelitian ini digunakan sebagai obat standar yang berkhasiat sebagai antiinflamasi dan imunosupresan. Deksametason merupakan glukokortikoid sintetis yang bersifat imunosupresan kuat yang dapat menghambat produksi sitokin yang diinduksi oleh lipopolisakarida (Chuang et al., 2017).

Gambar 2 menunjukkan bahwa deksametason menunjukkan penghambatan pada ekspresi iNOS, IL-6, TNF- $\alpha$, TLR4 dan NF-kB dibandingkan dengan kontrol LPS. Hal ini sesuai dengan teori yang menyatakan bahwa efek deksametason yakni sebagai imunosupresan. IL-6, TNF- $\alpha$ merupakan sitokin proinflamatori, sedangkan NF-kB merupakan faktor transkripsi yang mengkontrol sejumlah gen penting pada proses imunitas dan inflamasi (Martins et al., 2016).

Makrofag merupakan sel imun bawaan (innate immune) yang mempunyai peranan penting pada respon inflamasi. Aktivasi makrofag oleh stimulus inflamasi seperti lipopolisakarida (LPS) akan memicu pelepasan berbagai mediator inflamasi dan sitokin seperti IL-6 dan TNF- $\alpha$ (Murray \& Wynn, 2011). TLR4 (toll like receptor 4 ) merupakan suatu protein homologous pada membran sel APC (antigen presenting cell) yang dapat mengenali lipopolisakarida (LPS) dari bakteri Gram negatif. Selanjutnya TLR4 yang sudah mengenali LPS dapat memicu respon innate immune dengan menginduksi sinyal tranduksi yang memproduksi sitokin proinflamasi untuk melawan patogen (Hikmah \& Dewanti, 2011). Pengikatan LPS dengan TLR4 akan menginduksi fosforilasi dan akhirnya mengaktifkan NFkB (Nuclear Factor-kappa B) suatu faktor yang mengatur transkripsi DNA untuk mengatur ekspresi gen yang menyandi protein pada berbagai proses biologis. Dengan adanya stimulasi seluler, selanjutnya akan menginduksi transkripsi gen proinflamasi dengan menghasilkan sitokin proinflamasi seperti siklooksigenase-2 (COX-2), iNOS, IL-6, IL-1 $\beta$, TNF- $\alpha$ dan prostaglandin (PGE2) (Muniandy et al., 2018). Inflamasi merupakan bentuk pertahanan tubuh terhadap kerusakan jaringan, masuknya agen asing, termasuk infeksi. Namun apabila respon 
inflamasi terjadi terus menerus (jangka panjang) dapat merusak jaringan sehingga dapat menimbulkan berbagai penyakit kronis seperti diabetes, gangguan jantung, sehingga untuk mencegah hal tersebut diperlukan suatu agen antiinflamasi (Ahmed, 2011). Gambar 2 menunjukkan bahwa ekstrak dan fraksi buah talok (EMBT, FHBT, FDBT dan FEABT) menurunkan ekspresi gen inflamasi seperti iNOS, TNF- $\alpha$, IL-6 dibandingkan kelompok kontrol LPS. Namun efek antiinflamasi FHBT relatif lebih besar dalam menurunkan ekspresi gen inflamasi seperti NF-kB, iNOS dan TNF- $\alpha$ dibandingkan EMBT dan FDBT, hal ini dimungkinkan karena FHBT yang bersifat non polar. Sementara FEABT juga menunjukkan penurunan dalam ekspresi gen IFN- $\gamma$, iNOS, TNF- $\alpha$, IL-6, NF-kB, namun penurunannya tidak signifikan dibanding kontrol LPS (Gambar 2). Hal ini sesuai dengan penelitian sebelumnya yang menyatakan bahwa buah talok mempunyai aktivitas sebagai antiinflamasi (Preethi et al., 2012).
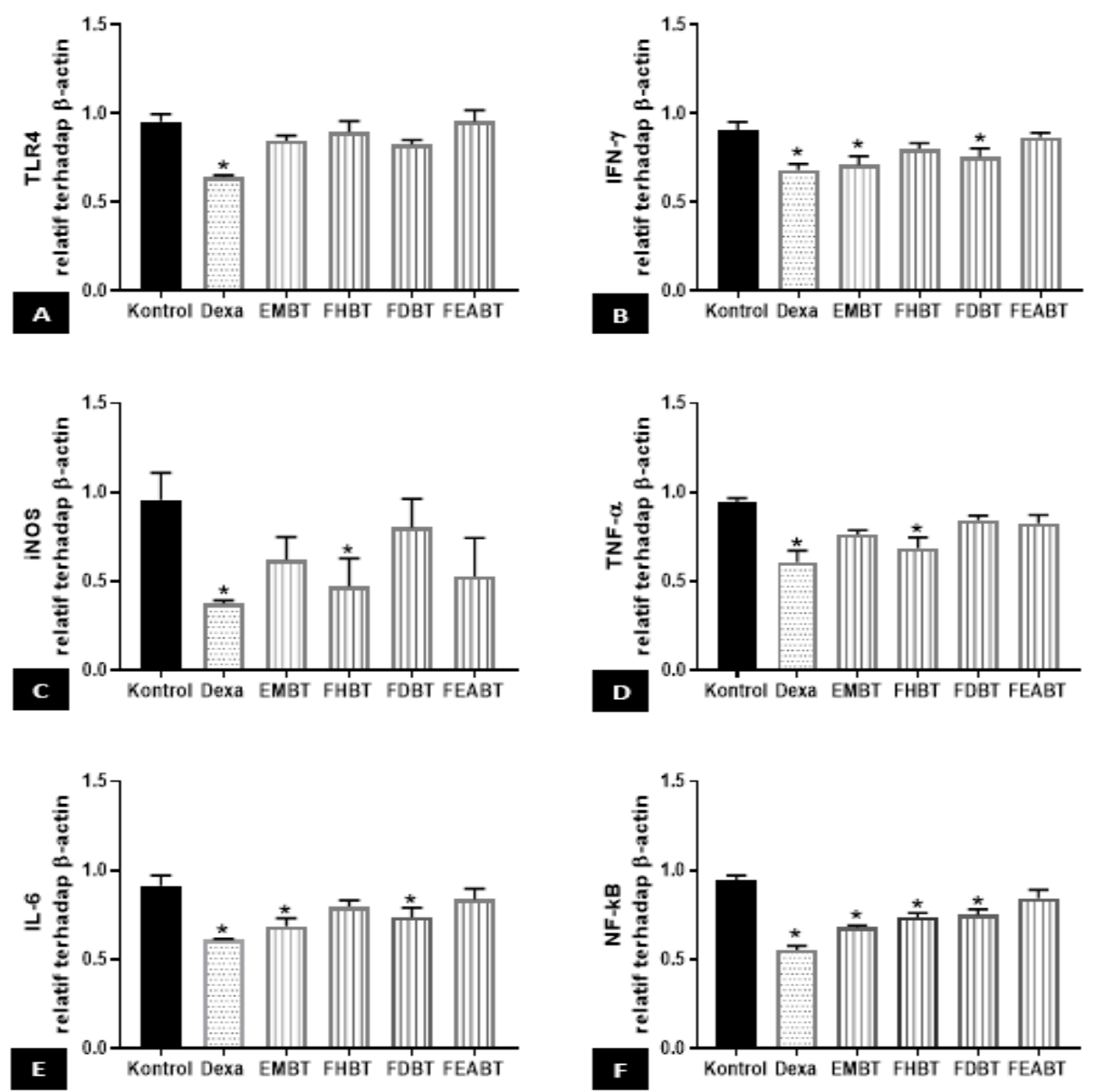

Gambar 2. Ekspresi gen TLR4 (A), IFN- $\gamma$ (B), iNOS (C), TNF- $\alpha$, IL-6 (E), NF-kB (F) relatif terhadap $\beta$-actin pada sel RAW 264.7 yang diinduksi lipopolisakarida $(n=3)$. * menunjukkan perbedaan yang bermakna dibandingkan kelompok kontrol LPS $(\mathrm{P}<0,05)$

Buah talok memiliki efek antiinflamasi, hal ini dimungkinkan karena adanya kandungan kimia seperti flavonoid, fenolik, triterpenoid yang diduga bisa menghambat ekspresi gen-gen 
proinflamatori (Tungmunnithum et al., 2018; Yahfoufi et al., 2018). Beberapa studi in vitro dan in vivo sebelumnya menunjukkan bahwa senyawa polifenol dapat menekan makrofag melalui penghambatan berbagai regulator respon inflamasi yakni dengan menghambat inducible nitric oxice synthase (iNOS), cyclooxygenase-2 (COX-2) dan mengurangi produksi TNF- $\alpha$, interleukin $1 \beta$ (1L-1 $\beta$ ) dan ekspresi IL-6 (González et al., 2011). Sedangkan mekanisme flavonoid sebagai antiinflamasi antara lain melalui modulasi sinyal transduksi dengan menurunkan transkripsi gen proinflamatori seperti NF-kB, menurunkan produksi sitokin TNF- $\alpha$ serta interleukin seperti IL-1, IL-6, selain itu juga memodulasi enzim proinflamatori dengan menurunkan mediator inflamasi seperti nitrit oksid (NO), leukotrien dan prostaglandin (García-Lafuente et al., 2009). Sitokin lain seperti IFN- $\gamma$ juga bisa dihambat oleh flavonoid seperti quercetin (Okamoto et al., 2002; Yahfoufi et al., 2018).

Hasil penelitian sebelumnya menunjukkan bahwa fraksi heksan buah talok (FHBT) mempunyai kandungan total fenolik dan flavonoid yang paling kecil, dibandingkan ekstrak dan fraksi lainnya. Kadar total fenolik (gallic acid equivalent) FHBT, FDBT, EMBT, dan FEABT berturut-turut 111,16 $\pm 2,66 ; 167,22 \pm 3,06 ; 279,09 \pm 6,20$; dan 301,06 $\pm 4,55 \mathrm{mg}$ GAE/g

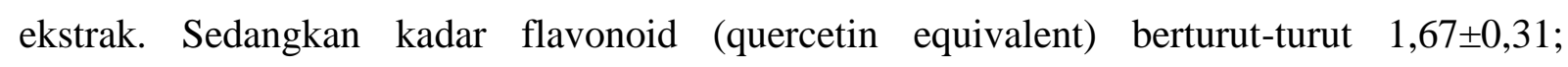
$30,68 \pm 1,35 ; 40,74 \pm 2,19$ dan 18,58 $\pm 0,39 \mathrm{mg} \mathrm{QE} / \mathrm{g}$ ekstrak (Sujono et al., 2020). Buah talok selain mengandung karbohidrat, flavonoid, fenolik, juga mengandung terpenoid (Pereira et al., 2018). Meskipun kandungan fenolik dan flavonoid dalam FHBT lebih kecil dibanding fraksi yang lain, namun efek antiinflamasi yang dihasilkan dimungkinkan dari kandungan terpenoidnya. Studi sebelumnya menunjukkan bahwa terpenoid berperan pada proses antiinflamasi melalui mekanisme penghambatan pada faktor transkripsi gen NF-kB, ekspresi sitokin proinflamatori seperti TNF- $\alpha$, IL-6, IL-4, IL-2 dan juga iNOS (Kim et al., 2020; Prakash, 2017).

Penelitian ini menunjukkan bahwa ekstrak buah talok meningkatkan ekspresi gen TLR4 dibanding deksametason. Penelitian lanjutan baik menggunakan uji in siliko maupun uji in vitro diperlukan untuk pengembangan agen imunomodulator. Uji in siliko Molecular Docking perlu dilakukan diantaranya untuk memastikan adanya interaksi kandungan aktif dalam ekstrak tanaman dengan protein reseptor toll like receptor (TLR) (Darmawan et al., 2017). Salah satu kandungan kimia dalam buah talok yang diduga mempunyai efek imunomodulator adalah flavonoid. Bioavailabilitas flavonoid relatif kurang baik jika diberikan secara peroral sehingga perlu dibuat formulasi dalam bentuk nanopartikel (Fitri et al., 2020). 


\section{Kesimpulan}

Ekstrak metanolik dan fraksi buah talok (Muntingia calabura L.) mempunyai efek imunomodulator melalui penghambatan inflamasi dengan menurunkan ekspresi gen iNOS, TNF- $\alpha$, IL-6, NF-kB, dan IFN- $\gamma$ pada sel makrofag RAW 264.7 yang diinduksi lipopolisakarida.

\section{Ucapan Terimakasih}

Kami berterima kasih kepada Kementerian Riset, Teknologi, dan Pendidikan Tinggi Republik Indonesia atas pendanaan penelitian PDUPT tahun 2019. Terima kasih kepada dr. Nur Arfian, Ph,D (FKKMK UGM) dan Dr. Denny Satria (FF USU) yang telah memberikan primer oligonukleotida.

\section{Deklarasi Konflik Kepentingan}

Semua penulis menyatakan tidak ada konflik kepentingan terhadap naskah ini.

\section{Daftar Pustaka}

Ahmed, A. U. (2011). An overview of inflammation: Mechanism and consequences. Frontiers of Biology in China, 6(4), 274-281.

Auliafendri, N., Rosidah, Yuandani, Suryani, S., and Satria, D. (2019). The immunomodulatory activities of Picria Fel-Terrae lour herbs towards RAW 264.7 cells. Open Access Macedonian Journal of Medical Sciences, 7(1), 24-28.

Baratawidjaja, K. G., and Rengganis, I. (2016). Imunologi Dasar (11th ed.). Badan Penerbit Fakultas Kedokteran Universitas Indonesia.

Chuang, T. Y., Cheng, A. J., Chen, I. T., Lan, T. Y., Huang, I. H., Shiau, C. W., Hsu, C. L., Liu, Y. W., Chang, Z. F., Tseng, P. H., and Kuo, J. C. (2017). Suppression of LPSinduced inflammatory responses by the hydroxyl groups of dexamethasone. Oncotarget, 8(30), 49735-49748.

Darmawan, K. H., Martien, R., Erlangga, N. D., Sitohang, S. M., and Pambudi, H. (2017). Utilization Of Nano Ethanolic Extract Combination Chamber Bitter (Phyllanthus Niruri L.) And Garlic (Allium Sativum L.) As A Natural Immunomodulator In Nanoherbal Development, In Silico And In Vitro Study. JPSCR: Journal of Pharmaceutical Science and Clinical Research, 2(02), 110.

Dewi, K., Widyarto, B., Erawijantari, P., and Widowati, W. (2015). In vitro study of Myristica fragrans seed (Nutmeg) ethanolic extract and quercetin compound as antiinflammatory agent. International Journal of Research in Medical Sciences, 3(9), 23032310.

Fard, M., Arulselvan, P., Karthivashan, G., Adam, S., and Fakurazi, S. (2015). Bioactive extract from moringa oleifera inhibits the pro-inflammatory mediators in lipopolysaccharide stimulated macrophages. Pharmacognosy Magazine, 11(44), 556.

Fitri, D., Kiromah, N. Z. W., and Widiastuti, T. C. (2020). Formulasi Dan Karakterisasi Nanopartikel Ekstrak Etanol Daun Salam (Syzygium polyanthum) Pada Berbagai Variasi Komposisi Kitosan Dengan Metode Gelasi Ionik. JPSCR: Journal of Pharmaceutical Science and Clinical Research, 5(1), 61.

García-Lafuente, A., Guillamón, E., Villares, A., Rostagno, M. A., and Martínez, J. A. (2009). Flavonoids as anti-inflammatory agents: Implications in cancer and cardiovascular disease. Inflammation Research, 58(9), 537-552.

González, R., Ballester, I., López-Posadas, R., Suárez, M. D., Zarzuelo, A., MartínezAugustin, O., and Sánchez de Medina, F. (2011). Effects of flavonoids and other 
polyphenols on inflammation. Critical Reviews in Food Science and Nutrition, 51(4), $331-362$.

Grigore, A. (2017). Plant Phenolic Compounds as Immunomodulatory Agent. In Phenolic Compound-Biological Activity (pp. 75-88).

Hikmah, N., and Dewanti, I. D. A. R. (2011). Peran Toll Like Receptors (TLRs) pada Innate Immunity (the Role of Toll Like REceptors to Innate Immunity). Stomatognatic, 8(1), 21-26.

Joo, T., Sowndhararajan, K., Hong, S., Lee, J., Park, S. Y., Kim, S., and Jhoo, J. W. (2014). Inhibition of nitric oxide production in LPS-stimulated RAW 264.7 cells by stem bark of Ulmus pumila L. Saudi Journal of Biological Sciences, 21(5), 427-435.

Kim, T., Song, B., Cho, K. S., and Lee, I. S. (2020). Therapeutic potential of volatile terpenes and terpenoids from forests for inflammatory diseases. International Journal of Molecular Sciences, 21(6).

Kwon, D. H., Cheon, J. M., Choi, E.-O., Jeong, J. W., Lee, K. W., Kim, K. Y., Kim, S. G., Kim, S., Hong, S. H., Park, C., Hwang, H.-J., and Choi, Y. H. (2016). The Immunomodulatory Activity of Mori folium, the Leaf of Morus alba L., in RAW 264.7 Macrophages In Vitro . Journal of Cancer Prevention, 21(3), 144-151.

Martins, G. R., Gelaleti, G. B., Moschetta, M. G., Maschio-Signorini, L. B., and De Campos Zuccari, D. A. P. (2016). Proinflammatory and Anti-Inflammatory Cytokines Mediated by NF- $\kappa \mathrm{B}$ Factor as Prognostic Markers in Mammary Tumors. Mediators of Inflammation, 2016.

Muniandy, K., Gothai, S., Badran, K. M. H., Kumar, S. S., Esa, N. M., and Arulselvan, P. (2018). Suppression of proinflammatory cytokines and mediators in LPS-Induced RAW 264.7 macrophages by stem extract of alternanthera sessilis via the inhibition of the NF$\kappa \mathrm{B}$ pathway. Journal of Immunology Research, 2018.

Murray, P. J., and Wynn, T. A. (2011). Protective and pathogenic functions of macrophage subsets. Nature Reviews Immunology, 11(11), 723-737.

Okamoto, I., Iwaki, K., Koya-Miyata, S., Tanimoto, T., Kohno, K., Ikeda, M., and Kurimoto, M. (2002). The flavonoid kaempferol suppresses the graft-versus-host reaction by inhibiting type 1 cytokine production and $\mathrm{CD} 8+\mathrm{T}$ cell engraftment. Clinical Immunology, 103(2), 132-144.

Patel, S., and Vajdy, M. (2015). Induction of cellular and molecular immunomodulatory pathways by vitamin A and flavonoids. Expert Opinion on Biological Therapy, 15(10), 0 .

Pereira, G. A., Arruda, H. S., de Morais, D. R., Eberlin, M. N., and Pastore, G. M. (2018). Carbohydrates, volatile and phenolic compounds composition, and antioxidant activity of calabura (Muntingia calabura L.) fruit. Food Research International, 108(March), 264-273.

Prakash, V. (2017). Terpenoids as source of anti-inflammatory compounds. Asian Journal of Pharmaceutical and Clinical Research, 10(3), 68-76.

Prakosa, A. P. (2014). Imunomodulasi Ekstrak Buah Talok (Muntingia calabura Linn) terhadap Makrofag Peritoneum Tikus Wistar Jantan yang Diinduksi Actinobacillus actionycetemcomitans. Universitas Jendral Soedirman.

Preethi, K., Premasudha, P., and Keerthana, K. (2012). Anti-inflammatory activity of Muntingia calabura fruits. Pharmacognosy Journal, 4(30), 51-56.

Preethi, K., Vijayalakshmi, N., Shamna, R., and Sasikumar, J. M. (2010). In Vitro Antioxidant Activity of Extracts from Fruits of Muntingia calabura Linn . from India. Pharmacognosy Journal, 2(14), 11-18.

Rosidah, Yuandani, Widjaja, S. S., Lubis, M. F., and Satria, D. (2019). The Immunomodulatory Activities of Saurauia vulcani Korth Leaves towards RAW 264 . 7 cell. International Summit on Science Technology and Humanity (ISETH), 586-593. 
Sarimanah, J., Ketut Adnyana, I., Sukandar, E. Y., and Kurniati, N. F. (2017). The antirheumatic activity of Muntingia calabura L. Leaves ethanol extract and its fraction. Asian Journal of Pharmaceutical and Clinical Research, 10(1), 84-86.

Sasmito, E. (2017). Imunomodulator Bahan Alami. Rapha Publising Penerbit ANDI Yogyakarta.

Senet, M. R. M., Parwata, I. M. O. A., and Sudiarta, I. W. (2012). Kandungan Total Fenol dan Flavonoid dari Buah Kersen (Muntingia calabura) serta Aktivitas Antioksidannya. Jurnal Kimia, 11(2), 187-193.

Siddiqua, A., Premakumari, K. B., Sultana, R., Vithya, and Savitha. (2010). Antioxidant activity and estimation of total phenolic content of Muntingia calabura by colorimetry. International Journal of ChemTech Research, 2(1), 205-208.

Sujono, T. A., Kusumowati, I. T. D., and Munawaroh, R. (2020). Immunomodulatory Activity of Muntingia calabura L Fruits using Carbon Clearance Assay and Their Total Flavonoid and Phenolic Contents. Asian Journal of Pharmaceutical and Clinical Research, 13(2), 140-145.

Tungmunnithum, D., Thongboonyou, A., Pholboon, A., and Yangsabai, A. (2018). Flavonoids and Other Phenolic Compounds from Medicinal Plants for Pharmaceutical and Medical Aspects: An Overview. Medicines, 5(3), 93.

Yahfoufi, N., Alsadi, N., Jambi, M., and Matar, C. (2018). The immunomodulatory and antiinflammatory role of polyphenols. Nutrients, 10(11), 1-23.

Yanti, Pramudito, T. E., Nuriasari, N., and Juliana, K. (2011). Lemon Pepper Fruit Extract (Zanthoxylum acanthopodium DC.) Suppresses the Expression of Inflammatory Mediators in Lipopolysaccharide-Induced Macrophages In Vitro. American Journal of Biochemistry and Biotechnology, 7(4), 190-195.

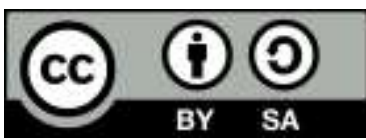

(C) 2021 by the authors. Submitted for possible open access publication under the terms and conditions of the Creative Commons Attribution-ShareAlike 4.0 International (CC BY-SA 4.0) license (https://creativecommons.org/licenses/by-sa/4.0/). 